\title{
BTCI enhances guanylin-induced natriuresis and promotes renal glomerular and tubular effects
}

\author{
Carvalho, AF. ${ }^{\mathrm{a}}$, Santos-Neto, MS. ${ }^{\mathrm{a}}$, Monteiro, HSA. ${ }^{\mathrm{a}}$, Freitas, SM. , \\ Morhy, L. ${ }^{\mathrm{b}}$, Nascimento, NRF. ${ }^{\mathrm{a}}$ and Fonteles, MC. ${ }^{\mathrm{c} *}$ \\ anstituto de Biomedicina - IBIMED, Universidade Federal do Ceará - UFC, CP 660434, Fortaleza, Ceará, Brazil \\ bLaboratório de Biofísica, Departamento de Biologia Celular, Universidade de Brasília, \\ CEP 70910-900, Brasília, DF, Brazil \\ 'Universidade Presbiteriana Mackenzie, Rua da Consolação, 896, Consolação, CEP 01302-907, São Paulo, SP, Brazil \\ *e-mail: reitoria@mackenzie.com.br
}

Received February 9, 2006 - Accepted July 19, 2006 - Distributed February 29, 2008

(With 1 figure)

\begin{abstract}
Guanylin and uroguanylin are small cysteine-rich peptides involved in the regulation of fluid and electrolyte homeostasis through binding and activation of guanylyl cyclases signaling molecules expressed in intestine and kidney. Guanylin is less potent than uroguanylin as a natriuretic agent and is degraded in vitro by chymotrypsin due to unique structural features in the bioactive moiety of the peptide. Thus, the aim of this study was to verify whether or not guanylin is degraded by chymotrypsin-like proteases present in the kidney brush-border membranes. The isolated perfused rat kidney assay was used in this regard. Guanylin $(0.2 \mu \mathrm{M})$ induced no changes in kidney function. However, when pretreated by the black-eyed pea trypsin and chymotrypsin inhibitor (BTCI - $1.0 \mu \mathrm{M}$; guanylin $-0.2 \mu \mathrm{M}$ ) it promoted increases in urine flow ( $\Delta \mathrm{UF}$ of $\left.0.25 \pm 0.09 \mathrm{~mL} \cdot \mathrm{g}^{-1} / \mathrm{min}, \mathrm{P}<0.05\right)$ and $\mathrm{Na}^{+}$excretion $\left(\% \Delta \mathrm{ENa}^{+}\right.$of $18.20 \pm 2.17$, $\mathrm{P}<0.05)$. BTCI $\left(1.0 \mu \mathrm{M}\right.$ ) also increased $\% \mathrm{ENa}^{+}$(from $22.8 \pm 1.30$ to $34.4 \pm 3.48, \mathrm{P}<0.05,90$ minutes). Furthermore, BTCI $(3.0 \mu \mathrm{M})$ induced increases in glomerular filtration rate (GFR; from $0.96 \pm 0.02$ to $1.28 \pm 0.02 \mathrm{~mL} . \mathrm{g}^{-1} / \mathrm{min}$, $\mathrm{P}<0.05,60$ minutes). The present paper strongly suggests that chymotrypsin-like proteases play a role in renal metabolism of guanylin and describes for the first time renal effects induced by a member of the Bowman-Birk family of protease inhibitors.
\end{abstract}

Keywords: natriuresis, kidney, Bowman-Birk protease inhibitors, BTCI, cyclic GMP, Vignia unguiculata.

\section{BTCI aumenta a natirurese induzida por guanilina e promove efeitos renais glomerulares e tubulares}

\begin{abstract}
Resumo
Guanilina e uroguanilina são peptídeos pequenos, ricos em cisteína, envolvidos na regulação da homeostase de fluidos e eletrólitos através da ligação e ativação da guanilato ciclase expressa no intestino e nos rins. A guanilina é menos potente do que a uroguanilina como agente natriurético e é degradada in vitro pela quimiotripsina devido a características estruturais únicas no domínio bioativo do peptídeo. Portanto o objetivo deste trabalho foi verificar se a guanilina é degradada por proteases tipo quimiotripsina, presentes na membrana da borda em escova dos rins. Para esta investigação, foi usado o modelo do rim isolado de rato perfundido. A Guanilina $(0,2 \mu \mathrm{M})$ não induziu mudanças na função renal. Entretanto, quando pré-tratada com inibidor de tripsina e de quimiotripsina de black-eyed pea (BTCI - 1,0 $\mu \mathrm{M}$; guanilina - 0,2 $\mu \mathrm{M}$ ) promoveu um aumento no fluxo urinário ( $\Delta \mathrm{UF}$ de $0,25 \pm 0,09 \mathrm{~mL} \cdot \mathrm{g}^{-1} / \mathrm{min}, \mathrm{P}<0,05$ ) e na excreção de $\mathrm{Na}^{+}\left(\% \Delta \mathrm{ENa}^{+}\right.$de $\left.18,20 \pm 2,17, \mathrm{P}<0,05\right)$. BTCI $(1,0 \mu \mathrm{M})$ também aumenta $\% \mathrm{ENa}^{+}($de $22,8 \pm 1,30$ a 34,4 $\pm 3,48$, $\mathrm{P}<0,0590$ minutos). Além disto, BTCI $(3,0 \mu \mathrm{M})$ induziu um aumento da taxa de filtração glomerular (GFR; de $0,96 \pm 0,02$ para $1,28 \pm 0,02 \mathrm{~mL} \cdot \mathrm{g}^{-1} / \mathrm{min}, \mathrm{P}<0,05,60$ minutos). O presente trabalho sugere fortemente que proteases semelhantes à quimiotripsina desempenham um papel no metabolismo renal de guanilinas e descreve, pela primeira vez, os efeitos renais induzidos por um membro da família de inibidores de proteases do tipo Bowman-Birk.
\end{abstract}

Palavras-chave: natriurese, rim, Inibidores de proteases tipo Bowman-Birk, BTCI, GMP cíclico, Vignia unguiculata. 


\section{Introduction}

Several heat-stable peptides produced by enteropathogenic bacteria are capable of inducing intestinal secretion via the intracellular second messenger, cyclic GMP (Hughes et al., 1978). The most extensively studied of these peptides is the E. Coli (Theodor Escherich, 1885) heat-stable enterotoxin (STa). The intestinal receptor for STa has been cloned and shown to belong to the family of particulate guanylyl cyclases (pGCs), and was named guanylate cyclase C (GC-C) (Schulz et al., 1990). STa also induces natriuresis and kaliuresis in the isolated perfused rat kidney (Lima et al., 1992). This action is mimicked by 8-Br-cGMP (Lima et al., 1992). Potential receptors bind selectively to $\mathrm{I}^{125}-\mathrm{STa}$ in several epithelia of the North American opossum, including the kidney (Forte et al., 1989).

Two endogenous peptides that share strong structural homology to STa were initially isolated from rat jejunum and opossum urine, and named guanylin and uroguanylin, respectively (Currie et al.,1992; Hamra et al., 1993). Both peptides activate the same signaling pathway of STa and also induce intestinal fluid and chloride secretion, as reviewed by Forte et al. (2000). In the isolated perfused rat kidney, both peptides elicit strong natriuretic and kaliuretic responses (Fonteles et al., 1998). Thus, guanylin and uroguanylin may influence kidney function via some physiological interactions involving the intracellular second messenger cGMP. A kidney guanylyl cyclase activated by guanylin/STa peptides was recently cloned from opossum kidney (OK) cells and named OKGC (London et al., 1999).

Greenberg and colleagues have demonstrated that guanylin but not uroguanylin is degraded in vitro by chymotrypsin (Greenberg et al., 1997). The potential explanation for this observation lies in the fact that guanylin has aromatic amino acids in its bioactive form (either phenylalanine or tyrosine, depending on the animal from which the peptides were isolated) and this structural feature makes it prone to cleavage by chymotrypsin (Forte et al., 2000, Greenberg et al., 1997).

The aim of this study was to investigate whether or not chymotrypsin-like proteases play a role in renal metabolism of guanylin. BTCI, a Bowman-Birk type protease inhibitor isolated from $V$. unguiculata (Linnaeus) Walpers, 1842 (cv Seridó) seeds was used as a pharmacological tool to test this hypothesis (Morhy and Ventura, 1987). BTCI is a stable globular protein whose complete primary sequence was determined by Morhy and Ventura (Morhy and Ventura, 1987). It contains a single polypeptide chain of 83 residues, including 14 half cysteines (Morhy and Ventura, 1987). The three dimensional model of the BTCI- $\alpha$-chymotrypsin complex has been recently developed (Freitas et al., 1997). BTCI contain two independent reactive sites that interact simultaneously with trypsin and chymotrypsin. Phe-43 is the key amino acid in the chymotrypsin reactive site and is located in the tip of a $\beta$-hairpin (Freitas et al., 1997).

\section{Materials and Methods}

Rat Guanylin (PNTCEICAYAACTGC - mol wt 1516) was synthesized by a solid-phase method and purified as described in detail elsewhere (Currie et al., 1992). BTCI was extracted from dry seeds and purified according to procedures described in previous papers (Ventura and Xavier-Filho, 1966). The protein was verified to be homogeneous by polyacrylamide gel electrophoresis, SDSpolyacrylamide gel electrophoresis and electrofocusing, as previously described (Ventura and Xavier-Filho, 1966). All chemicals were reagent grade and purchased from either Sigma (St. Louis, MO), Merck (West Point, PA) or American Peptide Corporation.

Adult Wistar-Kyoto rats from either sex weighing 250-300 g had tap water ad libitum, were fasted overnight and anesthetized with sodium pentobarbital (50 mg.kg-1 i.p.). The right kidney was perfused with a modified Krebs-Henseleit solution (MKHS) containing albumin $(6 \mathrm{~g} \%)$ for 120 minutes as control $(\mathrm{n}=12)$, according to experimental procedures described in detail by Fonteles et al. (1983). At 10 minutes intervals aliquots of both urine and perfusate were collected and analyzed for inulin by the method previously described by Wasler as modified by Fonteles and others (Fonteles et al., 1983; Wasler et al., 1955). Electrolytes were measured by flame photometry. Osmolality of the samples was determined in Advanced Instruments osmometer (Needham Heights, MA). Glomerular filtration rate (GFR), perfusion pressure (PP), urine flow (UF), as well as the fractional excretion of $\mathrm{Na}^{+}\left(\% \mathrm{ENa}^{+}\right)$and $\mathrm{K}^{+}\left(\% \mathrm{EK}^{+}\right)$were determined at 10 minutes intervals using the conventional clearance formula (MartinezMaldonato and Opava-Stitzer, 1978).

In the first experimental group, guanylin-only-treated group, guanylin $(0.2 \mu \mathrm{M})$ was added to perfusate reservoir after a 30 minutes internal control period and functional observations were made for 90 minutes. In the other group after 30 minutes of perfusion with BTCI $(1.0 \mu \mathrm{M})$, guanylin $(0.2 \mu \mathrm{M})$ was added to perfusate and experimental observations were made for the next 90 minutes. In the BTCI-only-treated group, BTCI $(0.3-3.0 \mu \mathrm{M})$ was added to perfusate reservoir after a 30 minutes internal control. In the control experiments the kidneys were perfused with MKHS for 120 minutes.

The data were averaged in triplicates at 30 minutes intervals and statistical analysis was carried out by one-way ANOVA and Student's $t$-test when applicable. In order to avoid the influence of individual variations between animals used in this study and to differentiate the effects of BTCI and guanylin, comparisons between various experimental groups were made based in the variation $(\Delta)$ of each group at 30 minutes intervals. Due to the same reasons mentioned above, the renal effects of BTCI were presented in this paper in absolute values compared with the 30 minutes internal control period of each group. Data are presented as means \pm SEM. There were at least four perfused kidneys for each data point. 


\section{Results}

The isolated perfused rat kidney control experiments were always very stable. Once placed in perfusate solution, after a 15 minutes equilibration period, all functional parameters remain stable throughout the experimental period (Table 1 and Figure 1).

Dose-response experiments suggested that BTCI was capable of inducing changes in renal function. Thus, BTCI (0.3-3.0 $\mu \mathrm{M})$ was evaluated for the ability to influence ex vivo renal function. BTCI even at the smallest concentration tested in this study promoted increases in $\% \mathrm{ENa}^{+}$(from $22.7 \pm 0.68 \%$ to $30.0 \pm 2.84 \%, \mathrm{P}<0.05,120$ minutes). However, in the range of concentrations tested in this study this effect was not dose-dependent (Table 1). Furthermore, BTCI $(3.0 \mu \mathrm{M})$ also promoted a sharp increase in PP (from
$110.1 \pm 1.66 \mathrm{mmHg}$ to $151.8 \pm 2.08 \mathrm{mmHg}, 120 \mathrm{~min}-$ utes, $\mathrm{P}<0.05)$. BTCI $(1.0 \mu \mathrm{M})$ promoted a strong but transient diuretic response (UF; from $0.13 \pm 0.01 \mathrm{~mL} . \mathrm{g}^{-1 /}$ $\min$ to $\left.0.26 \pm 0.02 \mathrm{~mL} \cdot \mathrm{g}^{-1} / \mathrm{min}, \mathrm{P}<0.05\right)$. An increase in $\% \mathrm{EK}^{+}$was also observed (from $43.2 \pm 3.19 \%$ to $65.7 \pm 9.67 \%, \mathrm{P}<0.05,90$ minutes, $1.0 \mu \mathrm{M})$. Moreover, BTCI $(3.0 \mu \mathrm{M})$ produced a large increase in GFR (from $0.96 \pm 0.02 \mathrm{~mL} . \mathrm{g}^{-1} / \mathrm{min}$ to $1.28 \pm 0.02 \mathrm{~mL} . \mathrm{g}^{-1} / \mathrm{min}, 60 \mathrm{~min}-$ utes, $\mathrm{P}<0.05)$. An increase in Cosm (BTCI-3.0 $\mu \mathrm{M}$ ) was also observed (from $0.13 \pm 0.02 \mathrm{~mL} . \mathrm{g}^{-1} / \mathrm{min}$ to $0.23 \pm 0.01$ $\mathrm{mLg}^{-1} / \mathrm{min}, \mathrm{P}<0.05,60$ minutes). Thus, in the range of concentrations tested, BTCI influenced many functional parameters determined in the present study.

On the other hand, guanylin $(0.2 \mu \mathrm{M})$ produced no effects on kidney function (Figure 1). These results are in agreement to previous data obtained by Fonteles et al. (1998) using this bioassay.

Table 1. Data from control kidneys perfused with Krebs-Henseleit solution containing albumin $(6 \mathrm{~g} \%)$ and kidneys treated with BTCI $(0.3-3.0 \mu \mathrm{M})$.

\begin{tabular}{|c|c|c|c|c|}
\hline $\mathrm{UF}\left(\mathrm{mL} \cdot \mathrm{g}^{-1} / \mathrm{min}\right)$ & 30 minutes & 60 minutes & 90 minutes & 120 minutes \\
\hline Control & $0.15 \pm 0.02$ & $0.17 \pm 0.02$ & $0.17 \pm 0.02$ & $0.17 \pm 0.02$ \\
\hline BTCI $0.3 \mu \mathrm{M}$ & $0.21 \pm 0.02$ & $0.26 \pm 0.02$ & $0.24 \pm 0.01$ & $0.28 \pm 0.02 *$ \\
\hline BTCI $1.0 \mu \mathrm{M}$ & $0.13 \pm 0.01$ & $0.26 \pm 0.02 *$ & $0.20 \pm 0.01$ & $0.17 \pm 0.01$ \\
\hline BTCI $3.0 \mu \mathrm{M}$ & $0.24 \pm 0.02$ & $0.28 \pm 0.01$ & $0.26 \pm 0.01$ & $0.26 \pm 0.01$ \\
\hline $\operatorname{GFR}\left(\mathrm{mL} \cdot \mathrm{g}^{-1} / \mathrm{min}\right)$ & 30 minutes & 60 minutes & 90 minutes & 120 minutes \\
\hline Control & $0.69 \pm 0.09$ & $0.66 \pm 0.09$ & $0.65 \pm 0.09$ & $0.65 \pm 0.09$ \\
\hline BTCI $0.3 \mu \mathrm{M}$ & $0.86 \pm 0.10$ & $0.90 \pm 0.09$ & $0.97 \pm 0.02 *$ & $0.87 \pm 0.04$ \\
\hline BTCI $1.0 \mu \mathrm{M}$ & $0.59 \pm 0.06$ & $0.75 \pm 0.07 *$ & $0.51 \pm 0.07$ & $0.47 \pm 0.05$ \\
\hline BTCI $3.0 \mu \mathrm{M}$ & $0.96 \pm 0.02$ & $0.75 \pm 0.07 *$ & $1.00 \pm 0.06$ & $1.07 \pm 0.07$ \\
\hline $\mathrm{PP}(\mathrm{mmHg})$ & 30 minutes & 60 minutes & 90 minutes & 120 minutes \\
\hline Control & $122.1 \pm 3.17$ & $122.3 \pm 3.40$ & $120.3 \pm 2.27$ & $121.8 \pm 3.62$ \\
\hline BTCI $0.3 \mu \mathrm{M}$ & $118.7 \pm 1.42$ & $114.8 \pm 3.25$ & $120.8 \pm 7.00$ & $120.0 \pm 4.64$ \\
\hline BTCI $1.0 \mu \mathrm{M}$ & $110.0 \pm 2.28$ & $139.0 \pm 4.98 *$ & $129.0 \pm 6.36$ & $122.0 \pm 6.31$ \\
\hline BTCI $3.0 \mu \mathrm{M}$ & $110.1 \pm 1.66$ & $122.1 \pm 2.96^{*}$ & $138.1 \pm 0.88 *$ & $151.1 \pm 2.08^{*}$ \\
\hline$\% \mathrm{ENa}^{+}$ & 30 minutes & 60 minutes & 90 minutes & 120 minutes \\
\hline Control & $20.6 \pm 1.31$ & $19.8 \pm 1.37$ & $20.2 \pm 1.37$ & $19.7 \pm 1.37$ \\
\hline BTCI $0.3 \mu \mathrm{M}$ & $22.7 \pm 0.68$ & $26.7 \pm 2.30$ & $23.0 \pm 2.51$ & $30.0 \pm 2.84^{*}$ \\
\hline BTCI $1.0 \mu \mathrm{M}$ & $22.8 \pm 1.30$ & $32.9 \pm 1.99$ & $34.4 \pm 2.80 *$ & $31.8 \pm 4.28 *$ \\
\hline BTCI $3.0 \mu \mathrm{M}$ & $24.8 \pm 1.20$ & $20.9 \pm 1.12$ & $23.8 \pm 0.67$ & $21.4 \pm 0.37$ \\
\hline$\% \mathrm{EK}^{+}$ & 30 minutes & 60 minutes & 90 minutes & 120 minutes \\
\hline Control & $30.0 \pm 2.56$ & $25.4 \pm 2.56$ & $24.6 \pm 2.56$ & $24.7 \pm 2.56$ \\
\hline BTCI $0.3 \mu \mathrm{M}$ & $35.5 \pm 2.84$ & $48.8 \pm 6.29^{*}$ & $49.3 \pm 9.10$ & $40.7 \pm 3.95$ \\
\hline BTCI $1.0 \mu \mathrm{M}$ & $43.2 \pm 3.19$ & $55.2 \pm 5.70$ & $65.7 \pm 9.67 *$ & $58.5 \pm 8.94 *$ \\
\hline BTCI $3.0 \mu \mathrm{M}$ & $32.9 \pm 1.31$ & $29.3 \pm 1.86$ & $37.7 \pm 0.93$ & $35.3 \pm 0.71$ \\
\hline $\operatorname{Cosm}\left(\mathrm{mL} \cdot \mathrm{g}^{-1} / \mathrm{min}\right)$ & 30 minutes & 60 minutes & 90 minutes & 120 minutes \\
\hline Control & $0.13 \pm 0.02$ & $0.13 \pm 0.02$ & $0.14 \pm 0.02$ & $0.13 \pm 0.02$ \\
\hline BTCI $0.3 \mu \mathrm{M}$ & $0.21 \pm 0.02$ & $0.25 \pm 0.02$ & $0.22 \pm 0.01$ & $0.26 \pm 0.02$ \\
\hline BTCI $1.0 \mu \mathrm{M}$ & $0.13 \pm 0.02$ & $0.23 \pm 0.01 *$ & $0.17 \pm 0.01$ & $0.14 \pm 0.09$ \\
\hline BTCI $3.0 \mu \mathrm{M}$ & $0.25 \pm 0.04$ & $0.28 \pm 0.01$ & $0.25 \pm 0.01$ & $0.24 \pm 0.02$ \\
\hline
\end{tabular}

a) GFR, PP, Cosm, $\% \mathrm{EK}^{+}, \% \mathrm{ENa}^{+}$and $\mathrm{UF}$ are glomerular filtration rate, perfusion pressure, osmolar clearance, fractional excretion of potassium, fractional excretion of sodium and urine flow, respectively;

b) $* \mathrm{P}<0.05$, compared to the 30 minutes internal control of the respective group (ANOVA and Student's $t$-test). 

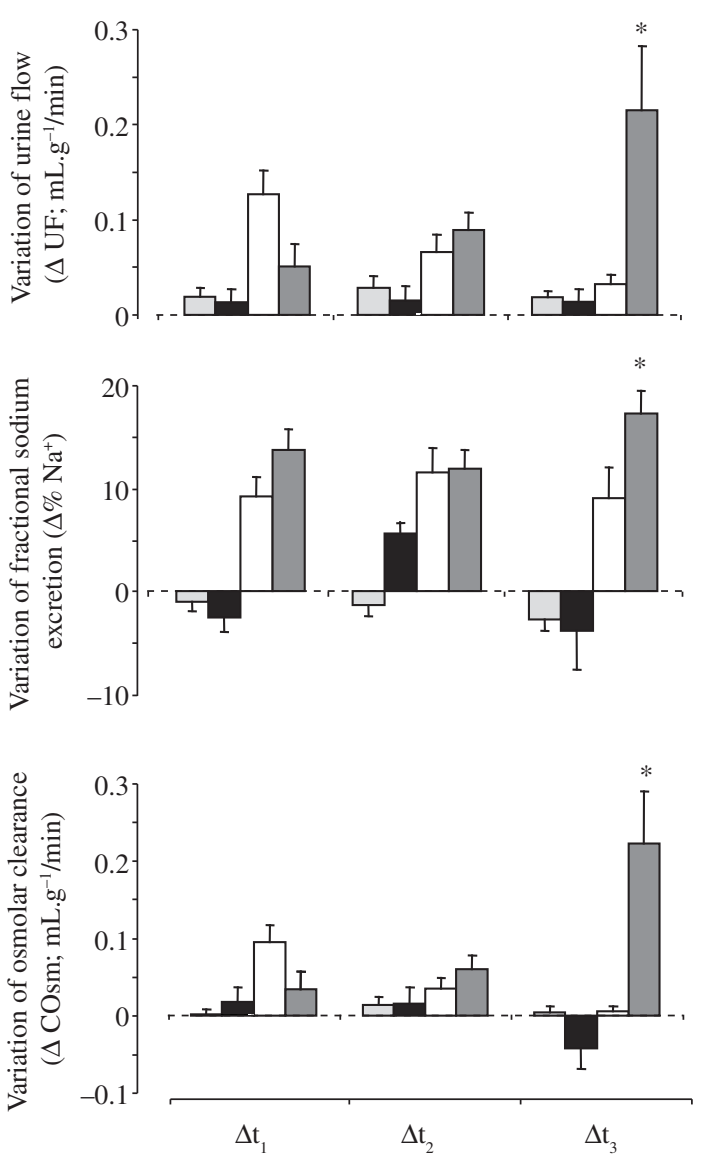

Control $\square$ Guanylin $(0.2 \mu \mathrm{M})$ BTCI $(1.0 \mu \mathrm{M})$

Guanylin $(0.2 \mu \mathrm{M})+$ BTCI $(1.0 \mu \mathrm{M}) \quad * \mathrm{p}<0.05$

Figure 1. Variation of the fractional $\mathrm{Na}^{+}$excretion $\left(\Delta \% \mathrm{ENa}^{+}\right)$, urine flow $(\Delta \mathrm{UF})$ and osmolar clerance $(\Delta$ Cosm) changes promoted by guanylin, BTCI and guanylin plus BTCI in kidneys perfused with modified KrebsHenseleit solution at the concentrations shown in the legend. $\mathrm{P}<0.05$, compared with all other groups at the same time (ANOVA and Student's $t$-test). $\Delta \mathrm{t} 1, \Delta \mathrm{t} 2$ and $\Delta \mathrm{t} 3$ are 30 minutes experimental periods where functional observations were made within each group and then compared. See text for further details.

BTCI pretreatment promoted a significant increment in the variation of fractional $\mathrm{Na}^{+}$excretion induced by guanylin at subthreshold concentrations that was independent of its intrinsic effects $\left(\Delta \% \mathrm{ENa}^{+}\right.$of $18.20 \pm 2.17 \%$, $\Delta \mathrm{t} 3, \mathrm{P}<0.05$, compared with all other groups; Figure 1). A parallel increase in urine flow was also observed in guanylin-perfused after BTCI exposure ( $\triangle \mathrm{UF}$ of $0.25 \pm 0.09 \mathrm{~mL} \cdot \mathrm{g}^{-1} / \mathrm{min}, \mathrm{P}<0.05 ; \Delta \mathrm{t} 3$ Figure 1$)$. BTCI plus guanylin also induced an overwhelming increase in osmolar clearance $\left(\Delta\right.$ Cosm of $0.23 \pm 0.08 \mathrm{~mL} \cdot \mathrm{g}^{-1} / \mathrm{min}$, $\mathrm{P}<0.05, \Delta \mathrm{t} 3$; Figure 1). An increase in GRF was also verified (data not shown).

\section{Discussion}

Both proguanylin and uroguanylin/prouroguanylin levels are markedly increased in chronic renal failure (Nakazato et al., 1996). Noteworthy is the fact that this increase positively correlates with the magnitude of the decrease in the renal functioning mass (Nakazato et al., 1996). Thus, the kidney appears to play an important role in clearing guanylin from plasma.

In general, polypeptide hormones are removed from the renal circulation by two pathways (Rabkin and Kitaji 1983). The predominant pathway is glomerular filtration, which is followed by proximal tubular degradation. Depending on the structure of the peptide, hydrolysis proceeds either after contact with the brush-border membrane or after internalization, for complex peptides in a non-filtering pathway. Since BTCI is a medium size protein, it must be filtered by the glomerulus. However, we can not demonstrate what type of pathway predominates in guanylin metabolism. Guanylin is a small (15 amino acid) linear peptide, suggesting that the brush-border proteases may play a major role in guanylin renal metabolism. Therefore, proguanylin which is the main form of guanylin found in plasma (Forte et al., 2000) may undergo degradation by chymotrypsin-like proteases present in renal brush-border membranes. This in turn may explain the fact that guanylin is found only at a lowto-non-detectable levels in mammalian urine.

The fact that guanylin undergoes renal metabolism and that BTCI enhanced guanylin-induced natriuresis may explain the observation made by Fonteles et al. (1998) that uroguanylin is more potent than guanylin as a natriuretic peptide in the isolated perfused rat kidney. Greenberg and coworkers (1997) also demonstrated that uroguanylin induces a much higher increase in natriuresis in the in vivo urethra-sealed mouse model.

Despite the fact that circulating proguanylin levels greatly exceed the plasma levels of both uroguanylin and prouroguanylin, uroguanylin is the only biologically active peptide found in mammalian urine at appreciable concentrations as reviewed by Forte et al. (2000). This finding is a strong evidence that guanylin undergoes renal metabolism after glomerular filtration.

Uroguanylin instead of guanylin has been implicated as an intestinal natriuretic hormone as reviewed by Forte et al. (2000). One of the main reasons for this speculation is the fact that guanylin has not been easily isolated from mammalian urine, possibly because this peptide is fully degraded by renal proteases. Several pieces of evidence suggest that guanylin peptides produced within the kidney may participate in the complex array of physiological mediators that ensure salt balance in postprandial states (Forte et al., 2000; Potthast et al., 2001).

Evidence for this theory comprises the fact that plasma guanylin increases in parallel to the degree of renal dysfunction and ${ }^{125} \mathrm{I}$-labeled guanylin accumulates in the kidney what may indicate reduced guanylin renal metabolism (Date et al., 1996). Moreover, oral administration of uroguanylin stimulates fluid secretion in the 
intestine using the suckling mice as model but this is only achieved with guanylin when administered together with a protease inhibitor. Moreover, relatively high concentrations of bioactive uroguanylin were found in the urine of opossums, rats and humans in contrast to the low to undetectable levels of guanylin in the same species (Hamra et al., 1993; Kita et al., 1994; Hamra et al., 1996a; 1996b). Since proguanylin can be detected in plasma (Kuhn et al., 1993; Nakazato et al., 1994) and its mRNA can be identified in the kidney (Schulz et al., 1992) the very low level of guanylin in urine may be due to the degradation of guanylin by renal chymotripsinlike proteases in the renal tubules. Renal metabolism of this peptide may also explain why uroguanylin is more potent as natriuretic and kaliuretic than guanylin in the isolated perfused rat kidney (Fonteles et al., 1998).

The heat-stable enterotoxin from E. coli (STa) is referred as a long-lived GC-C superagonist and causes natriuresis and kaliuresis in the isolated perfused kidney (Lima et al., 1992). The tyrosine-alanine segment present at residue 9 in the sequence of guanylin is the only site absent in Sta and represents a potential chymotryptic site. This theory is reinforced by the fact that the replacement of tyrosine-alanine with asparagine-proline at that residue in the sequence of guanylin turns it resistant to protease (Carpick and Gariépy, 1993) and the blockade of guanylin degradation by another chymotrypsin inhibitor named chymostatin (Santos-Neto et al., 2003).

The present paper also describes for the first time in the literature renal functional effects of a Bowman-Birk protease inhibitor. Both amino acid sequencing and 3-D spatial modeling have demonstrated that BTCI share strong structural homology with other members of the BowmanBirk family of protease inhibitors. Thus, whether or not other members of the Bowman-Birk family of proteinase inhibitors exhibit renal effects is a question to be argued. Therefore, this hypothesis awaits further investigation. BTCI may also inhibit the degradation of some peptide mediators, including native guanylin that are constitutively produced by the kidney as demonstrated by Northern analysis and/or RT-PCR (Potthast et al., 2001; Carrithers et al., 2000), and this, in turn, may play a contributory role for some of the effects herein described.

Studies are currently underway in our laboratories to characterize the mechanisms of action of the renal effects of BTCI described in the present study as well as to identify the possible participation of other renal enzymes in the metabolism of guanylin.

The present work provides experimental evidence that supports the speculation showed in the literature that chymotrypsin-like protease found on kidney tubules may play a role in cleavage and inactivation of guanylin.

Acknowledgments - We gratefully appreciate the expert technical assistance of Silvia F. França with the animal preparations. Domingos Barreto contributed with biochemical determinations and Dr. Leonard Forte for the donation of the peptides. This research was funded by the National Research Council (CNPq-Brazil) and by the Dept. of Veterans Affairs Merit grants.

\section{References}

CARPICK, BW. and GARIEPY, J., 1993. The Escherichia coli heat-stable enterotoxin is a long-lived superagonist of guanylin. Infect Immun., vol. 61, no. 11, p. 4710-4715.

CARRITHERS, SL., TAYLOR, B., CAI, WY., JOHNSON, BR., OTTO, CE., GREENBERG, RN. and JACKSON, BA., 2000. Guanylyl cyclase-C receptor mRNA distribution along the rat nephron. Regul Pep, vol. 95 no. 1-3, p. 65-74.

CURRIE, MG., FORK, KF., KATO, J., MOORE, RJ., HAMRA, FK., DUFFIN, KL. and SMITH, CE., 1992. Guanylin: an endogenous activator of intestinal guanylate cylase. Proceedings of the Natl. Acad. Sci. USA, vol. 89 no. 3, p. 947-51.

DATE, Y., NAKAZATO, M., YAMAGUCHI, H., MIYAZATO, M., MATSUKURA, S., 1996. Tissue distribution and plasma concentration of human guanylin. Intern Med., vol. 35, no. 3, p. 171-5.

FONTELES, MC., COHEN, JJ., BLACK, JJ, and WERTHEIM, SJ,, 1983. Support of kidney function by long-chain fatty acids derived from renal tissue. Am J Physiol, vol. 224, no. 3, p. 235-46.

FONTELES, MC., GREENBERG, RN., MONTEIRO, HSA., CURRIE, MG. and FORTE, LR., 1998. Natriuretic and kaliuretic activities of guanylin and uroguanylin in the isolated perfused rat kidney. Am J Physiol, vol. 275 no. 2, pt. 2, p. 191-97.

FORTE, LR., KRAUSE, WJ. and FREEMAN RH., 1989. Eschericha coli heat-stable enterotoxin receptors: localization in opossum kidney, intestine and testis. Am J Physiol, vol. 257, no. 5 , pt. 2 , p. $874-81$.

FORTE, LR., LONDON, RM., KRAUSE, WJ. and FREEMAN RH., 2000. Mechanism of guanylin action via cyclic GMP in the kidney. Annu Rev Physiol, vol. 62, p. 673-95. Review.

FREITAS, SM., MELLO, LV., SILVA, MCM., VRIEND, G., NESHICH, G. and VENTURA, MM., 1997. Analysis of the black-eyed pea trypsin and chymotrypsin inhibitor- $\infty$ chymotrypsin complex. FEBS Lett, vol. 409, no. 2, p. 121-27.

GREENBERG, RN., HILL, M., CRYTZER, J., KRAUSE, WJ., EBER, SL., HAMRA, FK. and FORTE, LR., 1997. Comparison of effects of uroguanylin, guanylin and Eschericha coli enterotoxin STA On mouse intestine and kidney: evidence that uroguanylin is an intestinal natriuretic hormone. $J$ Invest Med, vol. 45, no. 5, p. 276-82.

HAMRA, FK., FAN, X., KRAUSE, WJ., FREEMAN, RH., CHIN, DT., SMITH, CE., CURRIE, MG. and FORTE, LR., 1996a. Prouroguanylin and proguanylin: purification from colon, structure, and modulation of bioactivity by proteases. Endocrinology., vol. 137, no. 1, p. 257-65.

HAMRA, FK., FORTE, LR., EBER, SL., PIDHORODDECKYJ, NV., KRAUSE, WJ., FREEMAN, RH., CHIN, DT., TOMPKINS, JA., FOK, KF., SMITH, CE., DUFFIN KL., SIEGEL, NR. and CURRIE MG, 1993. Uroguanylin: structure and activity of a second endogenous peptide that stimulates intestinal guanylate cyclase. Proc Nat Acad Sci USA, vol. 90, n. 22, p. 10464-8.

HAMRA, FK., KRAUSE, WJ., EBER, SL., FREEMAN, RH., SMITH, CE., CURRIE, MG. and FORTE, LR., 1996b. Opossum colonic mucosa contains uroguanylin and guanylin peptides. Am J Physiol., vol. 270, no. 4 pt. 1, G708-16.

HUGHES, JM., MURAD, F., CHANG, B. and GUERRANT, RL., 1978. Role of cyclic GMP in the action of heat-stable 
enterotoxin of Eschericha coli. Nat (London), vol. 271, no. 5647 , p. $755-56$.

KITA, T., SMITH, CE., FOK, KF., DUFFIN, KL., MOORE, WM., KARABATSOS, PJ., KACHUR, JF., HAMRA, FK., PIDHORODECKYJ, NV., FORTE, LR. and CURRIE, MG., 1994. Characterization of human uroguanylin: a member of the guanylin peptide family. Am J Physiol., vol. 266, no. 2, pt 2, p. 342-8.

KUHN, M., RAIDA, M., ADERMANN, K., SCHULZKNAPPE, P., GERZER, R., HEIM, JM. and FORSSMANN, WG., 1993. The circulating bioactive form of human guanylin is a high molecular weight peptide $(10.3 \mathrm{kDa})$. FEBS Lett., vol. 318 , no. 2 , p. $205-259$.

LIMA, AAM., MONTEIRO, HSA. and FONTELES, MC., 1992. The effects of Eschericha coli heat-stable enterotoxin in renal sodium tubular transport. Pharmacol Toxicol, vol. 70, no. 3, p. 163-67.

LONDON, RM., EBER, SL., VISWESWARIAH, SS., KRAUSE, WJ. and FORTE, LR., 1999. Structure and activity of OK-GC: kidney receptor activated by guanylin peptides. Am J Physiol, vol. 276, no. 6 pt. 2, p. 882-91.

MARTINEZ-MALDONADO, M. and OPAVA-STITZER S., 1978. Free water clearance curves during saline, manitol, glucose and urea diuresis in rats. $J$ Physiol, vol. 280, no. 487-97.

MORHY, L. and VENTURA, MM., 1987. The complete amino acid sequence of the Vigna unguiculata (L.) Walp. Seed trypsin and chymotrypsin inhibitor. An Acad Bras Ciênc, vol. 59, no. $1-2$, p. $71-81$.

NAKAZATO, M. YAMAGUCHI, H., KINOSHITA, H., KANGAWA, K., MATSUO, H., CHINO, N. and MATSUKURA, S., 1996. Identification of biologically active and inactive human uroguanylins in plasma and urine and their increases in renal insufficiency. Bioch Bioph Res Co, vol. 220, no. 3, p. 586-93.
NAKAZATO, M., YAMAGUCHI, H., SHIOMI, K., DATE, Y., FUJIMOTO, S., KANGAWA, K., MATSUO, H. and MATSUKURA, S., 1994. Identification of 10-kDa proguanylin as a major guanylin molecule in human intestine and plasma and its increase in renal insufficiency. Biochem Biophys Res Commun., 30; vol. 205, no. 3, p. 1966-75.

POTTHAST, R., EHLER, R., SCHEVING, LA., SINDIC, A., SCHLATTER, E. and KUHN, M., 2001, High salt intake increase uroguanylin expression in mouse kidney. Endocrinology, vol. 142 , no. 7, p. 3087-97.

RABKIN, R. and KITAJI, J., 1983. Renal metabolism of peptide hormones. Miner Electrol Metab, vol. 9, no. 4-6, p. 212-26.

SANTOS-NETO, MS., CARRITHERS, SL., CARVALHO, AF., MONTEIRO, HS., GREENBERG, RN., FORTE, LR. and FONTELES, MC., 2003. Guanylin and its lysine-containing analogue in the isolated perfused rat kidney: interaction with chymotrypsin inhibitor. Pharmacol Toxicol, vol. 92, no. 3, p. 114-20.

SCHULZ, S., CHRISMAN, TD., GARBERS, DL.,1992.Cloning and expression of guanylin. Its existence in various mammalian tissues. J Biol Chem, vol. 267, no. 23, p. 16019-21.

SCHULZ, S., CHRISTMAN, TD., YUEN, PST. and GARBERS, DL., 1990. Guanylyl cyclase is a heat-stable enterotoxin receptor. Cell, vol. 63, no. 5, p. 941-48.

VENTURA, MM. and XAVIER-FILHO, J., 1966, A trypsin and chymotrypsin inhibitor from black-eyed pea (V. Sinensis L.) I. Purication and partial characterization. An Acad Bras Ciênc, vol. 38 p. $553-66$.

WALSER, M., DAVIDSON, DG. and ORLOFF, J., 1955. The renal clearance of alkalistable inulin. J Clin Invest, vol. 34, no. 10 , p. $1520-23$. 